\title{
Effects of chestnut tannins on performance and antioxidative status of transition dairy cows
}

\author{
H. W. Liu, ${ }^{*}$ D. W. Zhou, ${ }^{* 1}$ and K. Li† \\ *Northeast Institute of Geography and Agroecology, Chinese Academy of Sciences, Jilin 130102, P. R. China \\ †Shandong Heshi Corp. Ltd., Shandong 266061, P. R. China
}

\begin{abstract}
This study was conducted to evaluate the effects of chestnut tannins (CT) on performance and antioxidative status of transition dairy cows. Twenty multiparous Chinese Holstein cows in late gestation were paired according to expected calving date and randomly assigned either to a diet supplemented with CT (CNT, 10 $\mathrm{g}$ of $\mathrm{CT} / \mathrm{kg}$ of diet, dry matter basis) or to an unsupplemented control (CON) diet from 3 wk prepartum to 3 wk postpartum. Blood samples were taken on d $-21,1$, 7 , and 21 relative to calving for analysis of superoxide dismutase (SOD), glutathione peroxidase (GSH-Px), total antioxidant capacity (T-AOC), and malondialdehyde (MDA). Liver samples were taken by puncture biopsy on $\mathrm{d} 1$ and 21 relative to calving for analysis of SOD, GSH-Px, and MDA. Data were analyzed for a completely randomized block design with repeated measures. The addition of CT had no significant effects on dry matter intake, body weight, body condition score, milk yield, 3.5\% fat-corrected milk yield, and milk composition but did decrease milk MDA and somatic cell score in transition dairy cows. Dry matter intake decreased from $\mathrm{d}-21$ to 0 and increased from d 1 to 21 relative to calving across treatments. During the experimental period, body weight and body condition score decreased, whereas milk MDA and somatic cell score increased across treatments. A time effect was also observed for plasma MDA, which peaked on d 1 relative to calving and remained higher than that on $\mathrm{d}$ -21 relative to calving across treatments. Addition of CT decreased MDA concentrations in plasma and liver. Neither time nor CT $\times$ time effects were observed for SOD and T-AOC in plasma and SOD and GSH-Px in liver; a time effect was observed for plasma GSH-Px, which peaked on $\mathrm{d} 1$ relative to calving and remained higher than those on $\mathrm{d}-21$ relative to calving across treatments. Addition of CT increased SOD, GSH-Px, and T-AOC activities in plasma and SOD and GSH-Px
\end{abstract}

Received April 7, 2013.

Accepted June 4, 2013.

${ }^{1}$ Corresponding author: zhoudaowei@neigae.ac.cn activities in liver. In conclusion, addition of CT might inhibit lipid peroxidation and increase antioxidant enzymes activities in plasma and liver of transition dairy cows. Supplementation of CT may be a feasible means to improve the antioxidative status of transition dairy cows.

Key words: antioxidative status, chestnut tannin, transition cow

\section{INTRODUCTION}

During the transition period of dairy cows, the increase in oxygen requirements with increased metabolic demands results in augmented production of oxygenderived free radicals (Weiss, 1998; Yuan et al., 2012). When generation of free radicals exceeds the body's antioxidant production capacity, oxidative stress develops (Castillo et al., 2005). Oxidative stress may contribute to an impaired immune function and an enhanced susceptibility of dairy cattle to periparturient diseases (LeBlanc et al., 2004; Sordillo and Aitken, 2009). Therefore, diets enriched with antioxidants that cope with an excess of free radicals produced upon oxidative stress could be used to reduce the incidence of heath disorders in transition dairy cows (Vázquez-Añón et al., 2008). For example, vitamin E supplementation reduced oxidative damage in liver from periparturient dairy heifers (Bouwstra et al., 2008).

Tannins, a type of natural antioxidant, are a complex group of water-soluble polyphenolic compounds arising from the metabolism of plants. They consist of one or more aromatic rings with one or more hydroxyl groups, which can combine with free radicals to form resonance-stabilized phenoxyl radicals. This structure confers strong antioxidant properties (Rice-Evans et al., 1996). Barreira et al. (2008) evaluated the in vitro antioxidant activities of chestnut tannins (CT; extracted from chestnut wood, Castanea sativa, which is rich in hydrolysable tannins) and found that CT exerted inhibitory effects on 2,2-diphenyl-1-picrylhydrazyl radical and lipid peroxidation in pig brain tissue. Moreover, the in vivo antioxidant activities of tannins were also observed in rabbits (CT, Liu et al., 2011) and lambs 
(quebracho tannins, Luciano et al., 2011; López-Andrés et al., 2013). Tannins, which are present in several feed resources used for livestock feeding, have been reported to affect several aspects of ruminant nutrition and product quality (Tabacco et al., 2006; Vasta et al., 2008). However, no information on the in vivo antioxidant properties of CT in dairy cows and its potential beneficial role for transition dairy cows has been reported. Thus, we hypothesized that CT could exhibit antioxidant properties and we designed this study to investigate the effects of dietary addition of CT on performance and antioxidative status of transition dairy cows.

\section{MATERIALS AND METHODS}

All procedures were approved by the Administration Office of Laboratory Animals, Northeast Institute of Geography and Agroecology, Chinese Academy of Sciences (Jilin, China).

\section{Animals, Diets, and Experimental Design}

Twenty multiparous Chinese Holstein cows in late gestation were paired according to expected calving date and randomly assigned to either a diet supplemented with chestnut tannins (CNT, $10 \mathrm{~g}$ of $\mathrm{CT} /$ $\mathrm{kg}$ of diet, DM basis) or an unsupplemented control diet $(\mathbf{C O N})$ from 3 wk prepartum to 3 wk postpartum. No differences $(P>0.1)$ were found in $\mathrm{BW}$ and BCS between treatment groups at the beginning of the study. To prepare the CNT diet, appropriate amounts of CT were applied into the mixer wagon to be mixed with other ingredients. Pre- and postpartum diets were formulated according to the recommended values from NRC (2001); ingredients and composition are given in Table 1. Dry matter was determined by oven drying at $105^{\circ} \mathrm{C}$ overnight (AOAC International, 1995; method 930.15). Ether extract was determined using a Soxhlet apparatus (AOAC International, 1995; method 945.16). Crude protein was measured by a Kjeldahl nitrogen analysis (AOAC International, 1995; method 954.01). Content of NDF was determined as described by Van Soest et al. (1991) using heat-stable amylase (A3306, Sigma, St. Louis, MO) and sodium sulfite, and expressed without residual ash. Starch was measured as described by Bach Knudsen (1997). The CT (SilvaTeam, San Michele di Mondovì, Italy) were extracted from chestnut wood by a heat and low-pressure treatment according to the manufacturer's information; only the water-soluble fraction was retained and subsequently dehydrated. The product was presented as a fine brown powder. Chemical composition of the batch used in this experiment was as follows: $76 \%$ tannins
(14\% condensed tannins), $18 \%$ nontannin, $5 \%$ water, and $1 \%$ insolubles (pH 3.3, $0.1 \mathrm{mg} / \mathrm{mL}$ solution) on a fresh matter basis. The total tannin contents, expressed as tannic acid equivalents, were measured according to the Folin-Ciocalteu method (Makkar et al., 1993). The condensed tannins content was determined as described by Porter et al. (1986).

Cows were housed in tiestall barns bedded with sawdust and fed a TMR for ad libitum intake with at least $10 \%$ of daily feed refusal. All cows were individually fed twice daily at 0800 and $1500 \mathrm{~h}$. Feed offered and refused was recorded daily, and daily samples were collected to determine DMI. Cows had free access to water.

Body weight and BCS ( 1 to 5 in 0.25-unit increments; Wildman et al., 1982) were recorded once weekly. Cows were milked twice daily at 0500 and $1600 \mathrm{~h}$, and production was recorded at each milking during the trial. Milk samples were collected weekly for analysis of fat, protein, lactose, and somatic cells by infrared analysis with a Milko Scan FT6000 (Foss Electric, Hillerød, Denmark). Milk malondialdehyde (MDA) concentration was measured according to Suriyasathaporn et al. (2006). In brief, $100 \mathrm{~mL}$ of milk sample was mixed with $1 \mathrm{~mL}$ of TCA on a vortex mixer. Then, $400 \mathrm{~mL}$ of thiobarbituric acid (TBA) was added. The mixture was boiled for 30 min and subsequently cooled by using tap water. The solution was measured 4 times by spectrophotometer (Leng Guang SFZ1606017568, Shanghai, China) at $532 \mathrm{~nm}$ against its blank reaction mixture (without TBA). The MDA concentration in milk was expressed in nanograms per milliliter.

Blood samples were taken on $\mathrm{d}-21,1,7$, and 21 relative to calving for evaluation of antioxidative status. Blood samples were taken from each cow via tail vein using heparin plasma tubes. Plasma was obtained by centrifuging (Himac CR22G2, Hitachi Koki Co. Ltd., Tokyo, Japan) at $3,000 \times g$ for $10 \mathrm{~min}$ at $4^{\circ} \mathrm{C}$ and frozen at $-20^{\circ} \mathrm{C}$ for subsequent analysis of superoxide dismutase (SOD), glutathione peroxidase (GSH-Px), total antioxidant capacity (T-AOC), and MDA.

\section{Liver Biopsy and Biochemical Assay}

Liver samples were taken by puncture biopsy (Dann et al., 2006) under local anesthesia (10 mL of lidocaine) on d 1 and 21 relative to calving. Liver samples were rinsed in saline, frozen in liquid nitrogen, and then stored at $-80^{\circ} \mathrm{C}$ for subsequent analysis of SOD, GSH$\mathrm{Px}$, and MDA.

Forty milligrams of frozen liver in $4 \mathrm{~mL}$ of homogenization buffer $(0.05 \quad M$ Tris- $\mathrm{HCl}, \mathrm{pH}$ 7.4, $1 \mathrm{~m} M$ EDTA, and $0.25 M$ sucrose) was homogenized on ice with a Polytron PT 3000 homogenizer (Kinematica AG, Lucerne, Switzerland) for $5 \mathrm{~s}$ at $13,500 \mathrm{rpm}$. The 
Table 1. Ingredient and nutrient composition of treatment diets

\begin{tabular}{|c|c|c|}
\hline Item & $\begin{array}{l}\text { Prepartum } \\
\text { diet }\end{array}$ & $\begin{array}{c}\text { Postpartum } \\
\text { diet }\end{array}$ \\
\hline \multicolumn{3}{|l|}{ Ingredient, $\%$ of DM } \\
\hline Corn silage & 54 & 26 \\
\hline Alfalfa silage & - & 27.6 \\
\hline Wheat straw & 22 & 2.2 \\
\hline Soybean meal, $47 \%$, solvent extracted & 20.5 & 17.4 \\
\hline Dry ground shelled corn & - & 22.1 \\
\hline Animal fat & 0.2 & 1.7 \\
\hline Calcium sulfate & 1.0 & - \\
\hline Calcium bicarbonate & - & 0.8 \\
\hline Sodium bicarbonate & - & 0.9 \\
\hline Magnesium sulfate & 0.8 & - \\
\hline Magnesium oxide & 0.4 & 0.3 \\
\hline Monocalcium phosphate & 0.3 & 0.2 \\
\hline Trace mineral salt ${ }^{1}$ & 0.4 & 0.6 \\
\hline Vitamin premix ${ }^{2}$ & 0.4 & 0.2 \\
\hline \multicolumn{3}{|l|}{ Nutrient composition, \% of DM } \\
\hline $\mathrm{DM}$ & 49.5 & 49.9 \\
\hline $\mathrm{CP}$ & 15.1 & 17.7 \\
\hline NDF & 43.3 & 27.5 \\
\hline NDF from forage & 41.4 & 23.9 \\
\hline Starch & 17.6 & 23.8 \\
\hline Ether extract & 2.5 & 5.4 \\
\hline Ash & 8.0 & 8.2 \\
\hline
\end{tabular}

homogenate was centrifuged at $3,000 \times g$ for $10 \mathrm{~min}$ at $4^{\circ} \mathrm{C}$, and the supernatant was stored at $-80^{\circ} \mathrm{C}$ until analysis. The activities of SOD, T-AOC, and GSH$\mathrm{Px}$, and the contents of MDA in homogenate and plasma were assayed using colorimetric methods with a spectrophotometer. The assays were conducted using commercial kits purchased from Nanjing Jiancheng Institute of Bioengineering (Nanjing, Jiangsu, China) according to the instructions of the manufacturer. The activity of SOD was measured by the xanthine oxidase method, which monitored the inhibition of reduction of nitro blue tetrazolium by the sample (Winterbourn et al., 1975). The activity of GSH-Px was detected with 5,5'-dithiobis(2-nitrobenzoic acid), and the change of absorbance at $412 \mathrm{~nm}$ was monitored using a spectrophotometer (Hafeman et al., 1974). The T-AOC was measured by the method of ferric reducing-antioxidant power (FRAP) assay (Benzie and Strain, 1996) and detected at $520 \mathrm{~nm}$ with the spectrophotometer. The MDA concentration was analyzed with 2-thiobarbituric acid, monitoring the change of absorbance at $532 \mathrm{~nm}$ with the spectrophotometer (Placer et al., 1996).

All samples were measured in triplicate, at appropriate dilutions, to give activities of the enzymes in the linear range of standard curves constructed with pure enzymes. The total protein content in the homogenate was measured by the Bradford method (Bradford, 1976). Bovine serum albumin was used as standard and absorbance was measured at $595 \mathrm{~nm}$. Enzyme activities were expressed in units per milligram of protein for liver tissue and units per milliliter for plasma. The MDA concentrations were expressed as nanomoles per milligram of protein for liver tissue and nanomoles per milliliter for plasma.

\section{Statistical Analysis}

Data were analyzed for a completely randomized block design using Proc Mixed (SAS Institute, 2004) with repeated measures. The model included block, treatment, time, and 2- and 3-way interactions as fixed effects, and cow as random effect. No block, block $\times$ treatment, block $\times$ time, or block $\times$ treatment $\times$ time effects were observed. Week or day was used as repeated measures using the first-order autoregressive covariance structure, which provided the best fit according to Sawa's Bayesian information criterion. Degrees of freedom were calculated using the Kenward-Roger option. Means were determined using least squares means statement. Treatment means were compared using the PDIFF option. Significance was declared at $P \leq 0.05$ and trends at $P<0.10$ and $P>0.05$.

\section{RESULTS AND DISCUSSION}

\section{Performance Parameters}

Least squares means for average DMI are shown in Table 2. Dry matter intake decreased $(P<0.05)$ from 
$\mathrm{d}-21$ to 0 and increased $(P<0.01)$ from $\mathrm{d} 1$ to 21 relative to calving across treatments. No significant $\mathrm{CT}$ and $\mathrm{CT} \times$ time effects were observed on DMI during the experimental period. Our findings were similar to work conducted by Benchaar et al. (2008), who found that a diet supplemented with quebracho tannins at the level of $0.45 \%$ of DM did not affect DMI of lactating dairy cows. Likewise, Baah et al. (2007) observed that dietary supplements of quebracho tannins at the level of $0.6 \%$ of DM did not affect DMI of heifers. However, the effects of tannins on feed intake in ruminants are controversial. Increases of DMI with tannins have been reported in cows (Woodward et al., 2001, 2.59\% tannins), and sheep (Carulla et al., 2005, 2.5\% tannins). Conversely, Dschaak et al. (2011) observed that supplementing quebracho condensed tannin extract at a rate of $3 \%$ of DM in the diet decreased the DMI of lactating dairy cows. They suggested that one possible reason for this finding could be reduced palatability. These results suggest that effects of tannins may vary with the source and concentration of tannins in the diet.

In the present study, BW and BCS decreased $(P<$ $0.01)$ across treatments during the experimental period, but neither $\mathrm{CT}$ nor $\mathrm{CT} \times$ time effects were observed. Addition of CT did not affect milk yield, 3.5\% FCM yield, milk protein percentage, milk fat percentage, or milk lactose percentage (Table 2). These results were in agreement with the observation of Dschaak et al. (2011), who reported that addition of quebracho condensed tannin extract did not affect milk yield or concentrations of milk fat, true protein, and lactose. Moreover, Benchaar et al. (2008) observed that addition of quebracho tannins did not affect milk yield and composition. Conversely, Aguerre et al. (2010) observed that addition of tannins at a rate of $0.45 \%$ of DM increased milk true protein concentration, but decreased milk true protein concentration at a rate of $1.8 \%$ of DM.

Malondialdehyde, one of the peroxidation products of lipids and a widely used indicator in milk, was measured to evaluate peroxidation status (Moore and Roberts, 1998; Miranda et al., 2004). In many countries, SCS is used as an indicator to monitor inflammation of the mammary gland and evaluate the hygienic milk quality (Suriyasathaporn et al., 2006). Suriyasathaporn et al. (2006) reported that SCS was positively related to MDA concentration in raw milk, suggesting a relationship between SCS and oxidative stress. In the present study, milk SCS increased $(P<0.05)$ across treatments during the experimental period. A similar tendency $(P$ $<0.1$ ) was observed for time effects on milk MDA. Addition of CT decreased $(P<0.05)$ SCS and MDA in milk. These results indicated that CT supplementation could alleviate oxidative stress and inflammation of the mammary gland in lactating cows.

\section{Lipid Peroxidation in Plasma and Liver}

Lipid peroxidation is one of important consequences of oxidative stress (Kumaraguruparan et al., 2002). Malondialdehyde is one of the lipid peroxidation products and is often used as an indicator of oxidative stress (Armstrong and Browne, 1994). In the present study, a time effect $(P<0.05)$ was observed for plasma MDA, which peaked on d 1 relative to calving and remained higher than that on $\mathrm{d}-21$ relative to calving

Table 2. Least squares means for DMI, BW, BCS, milk yield, milk SCS, milk malondialdehyde (MDA), and milk composition of cows fed diets with or without chestnut tannins (CT)

\begin{tabular}{|c|c|c|c|c|c|c|}
\hline \multirow[b]{2}{*}{ Item } & \multicolumn{2}{|c|}{ Treatment $^{1}$} & \multirow[b]{2}{*}{ SEM } & \multicolumn{3}{|c|}{$P$-value } \\
\hline & $\mathrm{CON}$ & CNT & & Treatment & Time & $\begin{array}{c}\text { Treatment } \\
\times \text { Time }\end{array}$ \\
\hline Prepartum DMI, kg/d & 9.9 & 10.8 & 0.44 & 0.56 & 0.03 & 0.65 \\
\hline Postpartum DMI, kg/d & 14.8 & 15.1 & 0.56 & 0.63 & $<0.01$ & 0.77 \\
\hline $\mathrm{BW}, \mathrm{kg}$ & 714 & 717 & 19.4 & 0.89 & $<0.01$ & 0.36 \\
\hline BCS & 3.11 & 3.16 & 0.11 & 0.81 & $<0.01$ & 0.47 \\
\hline Milk, kg/d & 29.5 & 30.3 & 1.57 & 0.63 & $<0.01$ & 0.51 \\
\hline $3.5 \% \mathrm{FCM},{ }^{2} \mathrm{~kg} / \mathrm{d}$ & 36.4 & 36.2 & 1.78 & 0.87 & $<0.01$ & 0.62 \\
\hline \multicolumn{7}{|l|}{ Milk composition, \% } \\
\hline Protein & 3.15 & 3.31 & 0.12 & 0.23 & $<0.01$ & 0.31 \\
\hline Fat & 4.94 & 4.70 & 0.19 & 0.11 & 0.23 & 0.26 \\
\hline Lactose & 4.51 & 4.68 & 0.10 & 0.25 & $<0.01$ & 0.20 \\
\hline $\mathrm{MDA}, \mathrm{ng} / \mathrm{mL}$ & 1,632 & 1,524 & 35.7 & 0.03 & 0.08 & 0.28 \\
\hline $\mathrm{SCS}^{3}$ & 3.78 & 2.37 & 0.38 & 0.04 & 0.03 & 0.13 \\
\hline
\end{tabular}

${ }^{1} \mathrm{CON}=$ control diet; $\mathrm{CNT}=10 \mathrm{~g}$ of $\mathrm{CT} / \mathrm{kg}$ of diet.

${ }^{2}$ Calculated according to NRC (2001) equation.

${ }^{3} \mathrm{SCS}=\log _{2}(\mathrm{SCC} / 100)+3$ (Shook, 1993). 
Table 3. Least squares means for plasma superoxide dismutase (SOD), glutathione peroxidase (GSH-Px), total antioxidant capacity (T-AOC), and malondialdehyde (MDA) concentrations of cows fed diets with or without chestnut tannins (CT)

\begin{tabular}{|c|c|c|c|c|c|c|c|}
\hline \multirow[b]{2}{*}{ Item } & \multirow[b]{2}{*}{ Day } & \multicolumn{2}{|c|}{ Treatment $^{1}$} & \multirow[b]{2}{*}{ SEM } & \multicolumn{3}{|c|}{$P$-value } \\
\hline & & $\mathrm{CON}$ & CNT & & Treatment & Time & $\begin{array}{c}\text { Treatment } \\
\times \text { Time }\end{array}$ \\
\hline T-AOC, U/mL & Overall mean & 3.07 & 5.10 & 0.21 & 0.04 & 0.65 & 0.12 \\
\hline \multirow[t]{3}{*}{ GSH-Px, U/mL } & Overall mean & 162.4 & 203.1 & 4.34 & 0.02 & $<0.01$ & $<0.01$ \\
\hline & $\mathrm{d}-21$ & $147.4^{\mathrm{a}}$ & $151.5^{\mathrm{a}}$ & 5.65 & & & \\
\hline & d 21 & $158.3^{\mathrm{ab}}$ & $190.5^{\mathrm{d}}$ & 5.63 & & & \\
\hline \multirow[t]{5}{*}{$\mathrm{MDA}, \mathrm{nmol} / \mathrm{mL}$} & Overall mean & 2.68 & 2.34 & 0.07 & 0.03 & 0.02 & 0.14 \\
\hline & $\mathrm{d}-21$ & $2.07^{\mathrm{a}}$ & $2.03^{\mathrm{a}}$ & 0.09 & & & \\
\hline & d 1 & $2.97^{\mathrm{b}}$ & $2.53^{\mathrm{c}}$ & 0.11 & & & \\
\hline & d 7 & $2.89^{\mathrm{b}}$ & $2.48^{\mathrm{c}}$ & 0.13 & & & \\
\hline & d 21 & $2.79^{\mathrm{b}}$ & $2.31^{\mathrm{c}}$ & 0.11 & & & \\
\hline
\end{tabular}

${ }^{\mathrm{a}-\mathrm{d}}$ Means in rows within a parameter with different superscripts differ $(P<0.05)$.

${ }^{1} \mathrm{CON}=$ control diet; $\mathrm{CNT}=10 \mathrm{~g}$ of $\mathrm{CT} / \mathrm{kg}$ of diet.

${ }^{2}$ Only overall means are reported because no significant time or time by treatment interaction effects were observed.

across treatments (Table 3). Likewise, Bernabucci et al. (2005) observed that plasma concentration of MDA began to increase during the last week of pregnancy and that values $30 \mathrm{~d}$ after calving were still higher than those observed before calving. Two possible factors explain this finding. First, the endocrine adjustment and increased metabolic demands imposed on the cow by the metabolism of fetus and milk production might markedly increase production of free radicals (Miller et al., 1993). Second, the physical effort of calving might generate free radicals because increased demand for energy activates mitochondrial respiration in the skeletal musculature and increases oxygen uptake by muscles (Avellini et al., 1999). Nevertheless, Chiaradia et al. (1998) reported that this physical effort had only a short-term effect in racehorses. In the present study, addition of CT decreased $(P<0.05)$ MDA concentrations in plasma and liver (Tables 3 and 4$)$. Tannin has been reported to prevent superoxide formation and lipid peroxidation (Lau and King, 2003). Yokozawa et al. (2000) fed tannins to rats and found that lipid peroxidation in plasma and tissues decreased significantly in the presence of supplemented tannins. Liu et al.
(2011) fed diets supplemented with CT to rabbits and found that addition of CT decreased lipid peroxidation in plasma and liver. Likewise, Zhong et al. (2011a) found that dietary tea tannins reduced plasma MDA concentration in goats. The inhibitory effects of CT on lipid peroxidation are possible due to the scavenging of free radicals depending on their chemical structures and activating endogenous antioxidant defenses against free radicals (Yeh and Yen, 2006; Liu et al., 2011).

\section{Antioxidant Enzymes in Plasma and Liver}

Several endogenous antioxidant enzymes such as SOD and GSH-Px can convert oxygen-derived free radicals into less dangerous forms (Halliwell and Chirico, 1993). Superoxide can first be degraded into hydrogen peroxide by SOD and subsequently catalyzed and converted into water by a series of enzymes including GSH-Px (Blokhina et al., 2003). In the present study, neither time nor $\mathrm{CT} \times$ time effects were observed on SOD and T-AOC in plasma or on SOD and GSH-Px in liver. Plasma GSH-Px, however, peaked on d 1 relative to calving and remained higher $(P<0.01)$ than on $\mathrm{d}-21$

Table 4. Least squares means for hepatic superoxide dismutase (SOD), glutathione peroxidase (GSH-Px), and malondialdehyde (MDA) concentrations of cows fed diets with or without chestnut tannins (CT)

\begin{tabular}{|c|c|c|c|c|c|c|}
\hline \multirow[b]{2}{*}{ Item } & \multicolumn{2}{|c|}{ Treatment $^{1}$} & \multirow[b]{2}{*}{ SEM } & \multicolumn{3}{|c|}{$P$-value } \\
\hline & $\mathrm{CON}$ & $\mathrm{CNT}$ & & Treatment & Time & $\begin{array}{c}\text { Treatment } \\
\times \text { Time }\end{array}$ \\
\hline SOD, U/mg of protein & 20.2 & 27.8 & 0.72 & 0.03 & 0.46 & 0.76 \\
\hline GSH-Px, $\mathrm{U} / \mathrm{mg}$ of protein & 91.3 & 109.6 & 2.41 & $<0.01$ & 0.19 & 0.31 \\
\hline $\mathrm{MDA}, \mathrm{nmol} / \mathrm{mg}$ of protein & 2.03 & 1.36 & 0.11 & 0.04 & 0.22 & 0.21 \\
\hline
\end{tabular}

${ }^{1} \mathrm{CON}=$ control diet; $\mathrm{CNT}=10 \mathrm{~g}$ of $\mathrm{CT} / \mathrm{kg}$ of diet. 
relative to calving across treatments (Tables 3 and 4 ). Likewise, Yuan et al. (2012) found no time effects on plasma SOD in transition dairy cows from wk 3 antepartum to wk 3 postpartum. Conversely, Bernabucci et al. (2002) observed that no time effects on plasma GSH-Px were observed from d -21 to 35 relative to calving in transition dairy cows but that cows showed increased plasma SOD around calving. Gessner et al. (2013) reported that mRNA abundances of $S O D$ and $G S H-P x$ in the liver of dairy cows decreased from wk 1 to 14 postpartum but remained higher than those in wk 3 antepartum. They suggested that these increases might be a physiologic means to prevent oxidative stress, which might be exacerbated by parturition.

In the present study, the addition of CT increased SOD $(P<0.01)$, GSH-Px $(P<0.05)$, and T-AOC $(P$ $<0.05)$ activities in plasma, and increased SOD $(P<$ $0.05)$ and GSH-Px $(P<0.01)$ activities in the liver of dairy cows (Tables 3 and 4 ). These results are in agreement with the observations of Krajka-Kuzniak and Baer-Dubowska (2003), who observed that activities of antioxidant enzymes were induced by tannic acid in the liver and kidney of rats. Moreover, López-Andrés et al. (2013) observed that dietary quebracho tannins increased the antioxidant capacity of plasma and liver in sheep. Likewise, Luciano et al. (2011) reported that supplementation of quebracho tannins in the diet of lambs produced an improvement in the overall antioxidant status parameters of muscle. The possible reason for these findings is that CT may selectively induce antioxidant enzyme gene expression, likely through activation of nuclear factor E2-related factor 2 (Nrf2). Yeh and Yen (2006) found that the mRNA abundances of hepatic SOD, GSH-Px, and catalase of phenolic acidsupplemented rats were higher than those in the control group, suggesting that the Nrf2 protein might play a key role in phenolic acid-induced antioxidant gene activation. Similarly, Zhong et al. (2011b) observed that tea tannins increased mRNA and protein expression levels of $S O D$ and GSH-Px in skeletal muscle cells of goat in vitro.

\section{CONCLUSIONS}

The use of CT had no adverse effects on DMI, BW, BCS, milk yield, or milk composition but did decrease milk MDA and SCS in transition dairy cows. Moreover, addition of CT might inhibit lipid peroxidation and increase antioxidant enzymes activities in plasma and liver of transition dairy cows. Our results demonstrate that dietary supplementation with $\mathrm{CT}$ has the potential to improve the antioxidative status of transition dairy cows. Further research needs to investigate the in vivo effects of tannins on the mRNA expression of antioxidant enzymes in dairy cows.

\section{ACKNOWLEDGMENTS}

The authors acknowledge the National Natural Science Foundation of China (grant nos. 31201819 and 31201820) and the Fund for Excellent Young Scientists of Northeast Institute of Geography and Agroecology, Chinese Academy of Sciences (Changchun, China; grant no. DLSYQ13002) for financing the research.

\section{REFERENCES}

Aguerre, M. J., M. A. Wattiaux, M. C. Capozzolo, P. Lencioni, and C. Cabral. 2010. Effect of quebracho-chestnut tannin extracts at two dietary crude protein levels on performance and rumen fermentation of dairy cows. J. Dairy Sci. 93(Suppl. 1):445. (Abstr.)

AOAC International. 1995. Official Methods of Analysis. 15th ed. AOAC International, Washington, DC.

Armstrong, D., and R. Browne. 1994. The analysis of free radicals, lipid peroxides, antioxidant enzymes and compounds related to oxidative stress as applied to the clinical chemistry laboratory. Adv. Exp. Med. Biol. 366:43-58.

Avellini, L., E. Chiaradia, and A. Gaiti. 1999. Effect of exercise training, selenium and vitamin $\mathrm{E}$ on some free radical scavengers in horses (Equus caballus). Comp. Biochem. Physiol. B Biochem. Mol. Biol. 123:147-154.

Baah, J., M. Ivan, A. N. Hristov, K. M. Koenig, L. M. Rode, and T. A. McAllister. 2007. Effects of potential dietary antiprotozoal supplements on rumen fermentation and digestibility in heifers. Anim. Feed Sci. Technol. 137:126-137.

Bach Knudsen, K. E. 1997. Carbohydrate and lignin contents of plant materials used in animal feeding. Anim. Feed Sci. Technol. $67: 319-338$.

Barreira, J. C. M., I. C. F. R. Ferreira, M. B. P. P. Oliveira, and J. A. Pereira. 2008. Antioxidant activities of the extracts from chestnut flower, leaf, skins and fruit. Food Chem. 107:1106-1113.

Benchaar, C., T. A. McAllister, and P. Y. Chouinard. 2008. Digestion, ruminal fermentation, ciliate protozoal populations, and milk production from dairy cows fed cinnamaldehyde, quebracho condensed tannin, or Yucca schidigera saponin extract. J. Dairy Sci. 91:4765-4777.

Benzie, I. F. F., and J. J. Strain. 1996. The ferric reducing ability of plasma (FRAP) as a measure of "antioxidant power", the FRAP assay. Anal. Biochem. 239:70-76.

Bernabucci, U., B. Ronchi, N. Lacetera, and A. Nardone. 2002. Markers of oxidative status in plasma and erythrocytes of transition dairy cows during hot season. J. Dairy Sci. 85:2173-2179.

Bernabucci, U., B. Ronchi, N. Lacetera, and A. Nardone. 2005. Influence of body condition score on relationships between metabolic status and oxidative stress in periparturient dairy cows. J. Dairy Sci. 88:2017-2026.

Blokhina, O., E. Virolainen, and K. V. Fagerstedt. 2003. Antioxidants, oxidative damage and oxygen deprivation stress: A review. Ann. Bot. 91:179-194

Bouwstra, R. J., R. M. A. Goselink, P. Dobbelaar, M. Nielen, J. R. Newbold, and T. Van Werven. 2008. The relationship between oxidative damage and vitamin E concentration in blood, milk, and liver tissue from vitamin E supplemented and nonsupplemented periparturient heifers. J. Dairy Sci. 91:977-987.

Bradford, M. M. 1976. A rapid and sensitive method for the quantitation of microgram quantities of protein utilizing the principle of protein-dye binding. Anal. Biochem. 72:248-254.

Carulla, J. E., M. Kreuzer, A. Machmüller, and H. D. Hess. 2005. Supplementation of Acacia mearnsii tannins decreases methano- 
genesis and urinary nitrogen in forage-fed sheep. Aust. J. Agric. Res. 56:961-970.

Castillo, C., J. Hernandez, A. Bravo, M. Lopez-Alonso, V. Pereira, and J. L. Benedito. 2005. Oxidative status during late pregnancy and early lactation in dairy cows. Vet. J. 169:286-292.

Chiaradia, E., L. Avellini, F. Rueca, A. Spaterna, F. Porciello, M. T. Antonioni, and A. Gaiti. 1998. Physical exercise, oxidative stress and muscle damage in racehorses. Comp. Biochem. Physiol. B Biochem. Mol. Biol. 119:833-836.

Dann, H. M., N. B. Litherland, J. P. Underwood, M. Bionaz, A. D'Angelo, J. W. McFadden, and J. K. Drackley. 2006. Diets during far-off and close-up dry periods affect periparturient metabolism and lactation in multiparous cows. J. Dairy Sci. 89:3563-3577.

Dschaak, C. M., C. M. Williams, M. S. Holt, J. S. Eun, A. J. Young, and B. R. Min. 2011. Effects of supplementing condensed tannin extract on intake, digestion, ruminal fermentation, and milk production of lactating dairy cows. J. Dairy Sci. 94:2508-2519.

Gessner, D. K., G. Schlegel, J. Keller, F. J. Schwarz, R. Ringseis, and K. Eder. 2013. Expression of target genes of nuclear factor E2related factor 2 in the liver of dairy cows in the transition period and at different stages of lactation. J. Dairy Sci. 96:1038-1043.

Hafeman, D. G., R. A. Sunde, and W. G. Hoekstra. 1974. Effect of dietary selenium on erythrocyte and liver glutathione peroxidase in the rats. J. Nutr. 104:580-587.

Halliwell, B., and S. Chirico. 1993. Lipid peroxidation: Its mechanism, measurement, and significance. Am. J. Clin. Nutr. 57:715S-724S.

Krajka-Kuzniak, V., and W. Baer-Dubowska. 2003. The effects of tannic acid on cytochrome P450 and phase II enzymes in mouse liver and kidney. Toxicol. Lett. 143:209-216.

Kumaraguruparan, R., R. Subapriya, J. Kabalimoorthy, and S. Nagini. 2002. Antioxidant profile in the circulation of patients with fibroadenoma and adenocarcinoma of the breast. Clin. Biochem. $35: 275-279$.

Lau, D. W., and A. J. King. 2003. Pre- and post-mortem use of grape seed extract in dark poultry meat to inhibit development of thiobarbituric acid reactive substances. J. Agric. Food Chem. 51:1602-1607.

LeBlanc, S. J., T. H. Herdt, W. M. Seymour, T. F. Duffield, and K. E. Leslie. 2004. Peripartum serum vitamin E, retinol, and betacarotene in dairy cattle and their associations with disease. J. Dairy Sci. 87:609-619.

Liu, H. W., X. F. Dong, J. M. Tong, and Q. Zhang. 2011. A comparative study of growth performance and antioxidant status of rabbits when fed with or without chestnut tannins under high ambient temperature. Anim. Feed Sci. Technol. 164:89-95.

López-Andrés, P., G. Luciano, V. Vasta, T. M. Gibson, L. Biondi, A. Priolo, and I. Mueller-Harvey. 2013. Dietary quebracho tannins are not absorbed, but increase the antioxidant capacity of liver and plasma in sheep. Br. J. Nutr. 14:1-8.

Luciano, G., V. Vasta, F. J. Monahan, P. López-Andrés, L. Biondi, M. Lanza, and A. Priolo. 2011. Antioxidant status, colour stability and myoglobin resistance to oxidation of longissimus dorsi muscle from lambs fed a tannin-containing diet. Food Chem. 124:10361042.

Makkar, H. P. S., M. Bluemmel, N. K. Borowy, and K. Becker. 1993. Gravimetric determination of tannins and their correlations with chemical and protein precipitation methods. J. Sci. Food Agric. 61:161-165.

Miller, J. K., E. Brzezinska-Slebodzinska, and F. C. Madsen. 1993. Oxidative stress, antioxidants and animal function. J. Dairy Sci. $76: 2812-2823$.

Miranda, M., M. Muriach, I. Almansa, E. Jareno, F. Bosch-Morell, F. J. Romero, and D. Silvestre. 2004. Oxidative status of human milk and its variations during cold storage. Biofactors 20:129-137.

Moore, K., and L. Roberts. 1998. Measurement of lipid peroxidation. Free Radic. Res. 28:659-671.

NRC. 2001. Nutrient Requirements of Dairy Cattle. 7th rev. ed. Natl. Acad. Press, Washington, DC.
Placer, Z. A., L. L. Cushman, and B. C. Johnson. 1996. Estimation of lipid peroxidation, malindialdehyde in biochemical system. Anal. Biochem. 16:359-367.

Porter, L. J., L. N. Hrstich, and B. G. Chan. 1986. The conversion of procyanidins and prodelphinidins to cyanidin and delphinidin. Phytochemistry 25:223-230.

Rice-Evans, C. A., N. J. Miller, and G. Paganga. 1996. Structureantioxidant activity relationships of flavonoids and phenolic acids. Free Radic. Biol. Med. 20:933-956.

SAS Institute. 2004. SAS/STAT 9.1 User's Guide. Version 9.1 ed. SAS Institute Inc., Cary, NC.

Shook, G. E. 1993. Genetic improvement of mastitis through selection on somatic cell count. Vet. Clin. North Am. Food Anim. Pract. 9:563-581.

Sordillo, L. M., and S. L. Aitken. 2009. Impact of oxidative stress on the health and immune function of dairy cattle. Vet. Immunol. Immunopathol. 128:104-109.

Suriyasathaporn, W., U. Vinitketkumnuen, T. Chewonarin, S. Boonyayatra, K. Kreausukon, and Y. H. Schukken. 2006. Higher somatic cell counts resulted in higher malondialdehyde concentrations in raw cows' milk. Int. Dairy J. 16:1088-1091.

Tabacco, E., G. Borreani, G. M. Crovetto, G. Galassi, D. Colombo, and L. Cavallarin. 2006. Effect of chestnut tannin on fermentation quality, proteolysis, and protein rumen degradability of alfalfa silage. J. Dairy Sci. 89:4736-4746.

Van Soest, P. J., J. B. Robertson, and B. A. Lewis. 1991. Methods for dietary fiber, neutral detergent fiber and nonstarch polysaccharides in relation to animal nutrition. J. Dairy Sci. 74:3583-3597.

Vasta, V., A. Nudda, A. Cannas, M. Lanza, and A. Priolo. 2008. Alternative feed resources and their effects on the quality of meat and milk from small ruminants. Anim. Feed Sci. Technol. 147:223246

Vázquez-Añón, M., J. Nocek, G. Bowman, T. Hampton, C. Atwell, P. Vázquez, and T. Jenkins. 2008. Effects of feeding a dietary antioxidant in diets with oxidized fat on lactation performance and antioxidant status of the cow. J. Dairy Sci. 91:3165-3172.

Weiss, W. P. 1998. Requirements of fat-soluble vitamins for dairy cows: A review. J. Dairy Sci. 81:2493-2501.

Wildman, E. E., G. M. Jones, P. E. Wagner, R. L. Boman, H. F. Troutt, and T. N. Lesch. 1982. A dairy cow body condition scoring system and its relationship to selected production characteristics. J. Dairy Sci. 65:495-501.

Winterbourn, C. C., R. E. Hawkins, M. Brain, and R. Carrell. 1975. The estimation of red cell superoxide dismutase activity. J. Lab. Clin. Med. 85:337-341.

Woodward, S. L., G. C. Waghorn, M. J. Ulyatt, and K. R. Lassey. 2001. Early indications that feeding Lotus will reduce methane emissions from ruminants. Proc. N.Z. Soc. Anim. Prod. 61:23-26.

Yeh, C. T., and G. C. Yen. 2006. Induction of hepatic antioxidant enzymes by phenolic acids in rats is accompanied by increased levels of multidrug resistance-associated protein mRNA expression. J. Nutr. 136:11-15.

Yokozawa, T., E. J. Cho, Y. Hara, and K. Kitani. 2000. Antioxidative activity of green tea treated with radical initiator 2-amidinopropane dihydrochloride. J. Agric. Food Chem. 48:5068-5073.

Yuan, K., R. D. Shaver, S. J. Bertics, M. Espineira, and R. R. Grummer. 2012. Effect of rumen-protected niacin on lipid metabolism, oxidative stress, and performance of transition dairy cows. J. Dairy Sci. 95:2673-2679.

Zhong, R. Z., W. J. Xiao, G. P. Ren, D. W. Zhou, C. Y. Tan, Z. L. Tan, X. F. Han, S. X. Tang, C. S. Zhou, and M. Wang. 2011a. Dietary tea catechin inclusion changes plasma biochemical parameters, hormone concentrations and glutathione redox status in goats. Asian-australas. J. Anim. Sci. 12:1681-1689

Zhong, R. Z., D. W. Zhou, C. Y. Tan, Z. L. Tan, X. F. Han, C. S Zhou, and S. X. Tang. 2011b. Effect of tea catechins on regulation of antioxidant enzyme expression in $\mathrm{H}_{2} \mathrm{O}_{2}$-induced skeletal muscle cells of goat in vitro. J. Agric. Food Chem. 59:11338-11343. 